\title{
Freeze Risk and Protection Measures of Satsuma Mandarins Grown in the Southeastern United States
}

\author{
Robert C. Ebel ${ }^{1,4}$, Monte Nesbitt ${ }^{2}$, William A. Dozier, Jr. ${ }^{3}$, and Fenny Dane ${ }^{3}$ \\ Department of Horticulture, Auburn University, 101 Funchess Hall, Auburn, AL 36849 \\ Additional index words. microsprinkler irrigation, high tunnel houses, cold tolerance, fruit quality
}

\begin{abstract}
The northern fringe of the Gulf of Mexico has an excellent climate for growing high-quality satsumas that are available in U.S. retail chain stores before most other citrus. In part because of high fruit quality, satsuma mandarin production grew into a major industry in Alabama, Louisiana, Mississippi, and the panhandle of Florida in the early 1900 s. Freeze protection measures were not sufficient to prevent devastation of the industry by severe freezes. For the period encompassing the late $1900 \mathrm{~s}$, freeze risk was estimated using a mathematical approach that determined killing temperature based on air temperature. Freeze injury was determined to occur 1 out of every 4 years on average, although the freezes tended to come in clusters that have as yet not been correlated with long-term climate patterns. Within-tree microsprinkler irrigation, which was not available in the early $1900 \mathrm{~s}$, has been shown to reduce the severity of injury. Within-tree microsprinkler irrigation allows full production the year after the freeze, whereas unprotected trees must be grown from the base or replanted. The northerly geographical limit in the southeastern United States whereby satsumas can be successfully grown commercially is currently not known. Methods of protecting the entire tree, including overtree microsprinkler irrigation plus windbreaks and high tunnel houses, are being evaluated. More cold-tolerant satsuma cultivars have been selected, but they reduce freeze risk by at most $2^{\circ} \mathrm{C}$ in this region compared with current commercial cultivars. Genetic modification is one possible mechanism for improving cold tolerance sufficiently to reduce freeze risk similar to that of the citrus industry in Florida.
\end{abstract}

Satsuma mandarins were introduced into Alabama in 1898 (Winberg, 1948a) and commercial interest developed in the following decades. By 1923, the industry expanded to 4856 ha of bearing and 2428 ha of nonbearing trees in Alabama and an additional 650 ha scattered throughout Florida, Mississippi, Louisiana, and Texas (Dozier, 1924). There were seven packing facilities that shipped fruit to 45 cities in the United States, Canada, and England (Dozier, 1924). Several freezes in the 1920s and 1930s injured trees along with two hurricane events that also damaged the crop (Winberg, 1948b). The freeze of 20 Nov. 1940 killed most trees, which essentially eliminated the commercial industry (Winberg, 1948c). There have been isolated attempts to revive the industry, but up to the late 1990 s, only scattered plantings of a few hectares with fruit sold in local markets existed. In part because of memories of the earlier history, there is currently strong interest in reviving the satsuma industry.

There are several reasons that justify an effort to stimulate development of a satsuma mandarin industry in this region. The climate along the northern coast of the Gulf of Mexico allows production of high-quality fruit (Ebel et al., 2004). Warmer regions produce fruit with acid levels that are too low for optimum flavor. Satsuma mandarins reach excellent eating quality before most other citrus are available in the marketplace. The principle cultivar grown in Alabama, 'Owari', ripens as early as late October (Ebel et al., 2004), which is before most other citrus

\footnotetext{
${ }^{1}$ Associate Professor. Current address: Southwest Florida Research and Education Center, University of Florida, IFAS, 2686 Hwy. 29 N., Immokalee, FL 34142 .

${ }^{2}$ Agricultural Program Associate I.

${ }^{3}$ Professor.

${ }^{4}$ To whom reprint requests should be addressed; e-mail rcebel@ufl.edu
}

are available in retail chain stores. Earlier maturing cultivars are currently being evaluated, but some appear to ripen as early as mid-September, which would extend the marketing season several weeks earlier. Furthermore, satsuma mandarins can be stored for up to 8 weeks (Campbell, 2005), and considering that marketing studies have indicated that satsuma mandarins grown in this region will compete successfully with other fresh citrus fruit in retail chain stores (Campbell et al., 2004, 2006), there is the potential for extending the marketing season several weeks into that of other citrus in the marketplace.

Although high-quality fruit can be grown in this region, the principle limitation for long-term production is still the threat of freezes. However, freeze protection measures that did not exist in the early 1900s, especially microsprinkler irrigation (Bourgeois and Adams, 1987; Bourgeois et al., 1990; Braud et al., 1981; Davies et al., 1987; Nesbitt et al., 2000; Parsons et al., 1991; Rieger, 1989; Rieger et al., 1985, 1986, 1988a, 1988b) and high tunnel plastic houses, are available today that reduce significantly the severity of freeze injury. Furthermore, more cold-hardy cultivars (Zhang et al., 2002) and the potential of genetic modification to enhance cold tolerance (Iba, 2002; Nolte et al., 1997) may reduce the risk of freeze injury. Satsuma mandarins represent a commercially viable option for this region, but the freeze risk is substantial.

\section{ESTIMATED FREEZE RISK}

The climate in the southeastern United States has undergone long-term periods that affect freeze risk. The century preceding the damaging freeze of 1835 was relatively warm as evidenced by the fact that unprotected orange trees were grown and reached full size in South Carolina and Georgia (Attaway,
1997). Freezes that caused injury to citrus as far south as central and southern Florida occurred in 1835, 1857, 1894, 1895, 1962, 1981, 1982, 1983, 1985, and 1989. In Alabama during the first half of the 1900s (1900 to 1948), severe freezes that injured satsumas occurred in 1924, 1928, 1930, 1933, and 1940 (Winberg, 1948b). Few recorded observations exist for injurious freeze events from 1948 to the present, so events were estimated using a mathematical approach that determined the killing temperature based on the level of acclimation by air temperature preceding a freeze and comparing the killing temperature to the minimum air temperature during freeze events (Ebel et al., 2005). Economically damaging freezes were estimated to have occurred 1 out of 4 years for unprotected trees in the 56-year study at Fairhope, AL (Ebel et al., 2005), which is approximately twice the historical freeze risk of citrus in central Florida (Attaway, 1997).

\section{FREEZE PROTECTION MEASURES}

In the early $1900 \mathrm{~s}$, the only means of protecting trees were by banking soil around the trunk, growing trees under pine or pecan trees, and the use of smudge pots (Williams, 1911). Banking soil preserved buds at the base of trunks, but several years were required for trees to reach full size. Pine trees and smudge pots offered protection from radiational freezes but provided little protection from advective freezes, which are the more severe freezes that occur in this region.

Microsprinkler irrigation uses sensible heat and the latent heat of fusion of water to maintain tree temperatures at or above $0{ }^{\circ} \mathrm{C}$. After early failures in development of this approach, it has gained wide popularity in commercial groves in the southeastern United States (Bourgeois and Adams, 1987; Bourgeois et al., 1990; Braud et al., 1981; Nesbitt et al., 2000; Parsons et al., 1991; 
Rieger et al., 1985). Use of microsprinkler irrigation for young trees to protect the lower trunk is similar in effect to soil banking but easier to implement once the system is established. The most significant benefit of microsprinkler irrigation is for mature trees when microsprinklers are placed within the canopy to protect the scaffold limbs. By protecting scaffold limbs, trees can be back into full production the year after a freeze (Nesbitt et al., 2000). One major limitation of this approach is the need for large quantities of water. In some areas, water is limited, which has stimulated research to identify the minimum amount required to maintain tree survival (Bourgeois and Adams, 1987; Bourgeois et al., 1990; Braud et al., 1981; Nesbitt et al., 2000; Parsons et al., 1991; Rieger et al., 1985). In Alabama, groundwater is currently not limiting in many parts of the southern counties where satsumas are grown.

The principle problem with within-tree microsprinkler irrigation is that the outer canopy can be killed (Nesbitt et al., 2002). If leaves are killed but not the fruiting wood, flowers will emerge but abscise (Ebel et al., 2000; Nesbitt et al., 2002). The outer canopy could be protected by overtree sprinkler irrigation, but this approach has been avoided in this region as a result of poor water coverage from the high winds associated with advective freezes, the freezes that cause the most severe injury. High winds are a problem for tree fruit production in various regions of the world, but wind breaks have reduced wind speeds within orchards sufficiently to allow successful commercial production. Wind breaks coupled with overtree microsprinkler irrigation may be possible as a means of protecting enough foliage to allow some production the year of the freeze. We have an experimental planting in its second leaf with pine that will provide a tall wind break and hollies growing underneath to fill in as lower pine branches senesce as the trees age. One potential limitation of overtree microsprinkler irrigation is excessive limb breakage from the weight of the ice.

\section{SUPERIOR COLD-TOLERANT GERMPLASM}

Satsuma mandarins on Poncirus trifoliata rootstock are cold-tolerant to $-10{ }^{\circ} \mathrm{C}$ when fully hardened, which is the most coldtolerant of the commercial Citrus species (Yelenosky, 1985). Occasionally, trees of apparent bud sports or mutated nucellar seedlings survive freezes below $-10^{\circ} \mathrm{C}$. Trees that survived $\mathrm{a}-12{ }^{\circ} \mathrm{C}$ freeze were selected in China (Hongwen Huang, Director of the Wuhan Institute of Botany, personal communication) and we have preliminary evidence from controlled freezer studies that they are more cold-hardy than more commonly grown cultivars (Zhang et al., 2002). However, potted trees tend to be less cold-hardy than mature, field-grown trees, so the maximum cold-hardiness of these selections is currently not known. Nevertheless, it is likely that these selections will reduce freeze risk at least slightly in this region (Ebel et al., 2005).

Superior cold-hardy citrus crops are currently being developed through interspecific and intergeneric crosses. Crosses that have received the most attention are those between Citrus sp. and Poncirus trifoliata, which is cold-hardy to $\approx-26{ }^{\circ} \mathrm{C}$ (Spiegel-Roy and Goldschmidt, 1996). Poncirus trifoliata, a facultative deciduous species, has been a good candidate for intergeneric crosses with Citrus sp. to enhance cold-hardiness (Tignor et al., 1998; Yelenosky et al., 1973), however, although the presence of poncirin has made production of commercially acceptable fruit quality difficult. Another approach to developing commercial Citrus sp. with superior cold tolerance is through genetic modification. Cold-hardiness of citrus is a multigenic process (Lang et al., 2005; Zhang et al., 2005a, 2005b) that will require much research to understand so that strategies to enhance cold-hardiness can be developed.

Although freeze risk for satsuma mandarin production in the southeastern United States is substantial, a recent Monte Carlo analysis (data not published) using estimated freeze risk by Ebel et al. (2005) indicates that at current wholesale prices, the industry can be profitable. What is not clear is how longterm climate trends, especially those related to global warming, may alter freeze risk as well as fruit quality. Citrus trees represent a very long-term investment, up to several decades assuming injury by climate extremes and pests are minimized. Understanding long-term climate trends will help agricultural industries shift in an economically viable manner. However, robust long-term climate predictions that would allow agricultural scientists to advise industry leaders on strategies for shifting agriculture to adjust to climate change currently do not exist.

\section{Literature Cited}

Attaway, J.A. 1997. A history of Florida citrus freezes. Florida Science Source, Inc., Lake Alfred, FL.

Bourgeois, W.J. and A.J. Adams. 1987. Lowvolume scaffold branch irrigation for citrus freeze protection. HortScience 22:48-50.

Bourgeois, W.J., A.J. Adams, and D.R. Stipe. 1990. Effectiveness of scaffold branch irrigation for freeze protection of Louisiana citrus during 1989 freeze. Proc. Florida. State Hort. Soc. 103:62-64.

Braud, H.J., P. Davidson, and P.L. Hawthorne 1981. Reduction of freeze loss in citrus with water spray. Trans. Amer. Soc. Agr. Eng. $24: 396-400$

Campbell, B., R. Nelson, R. Ebel, and W. Dozier. 2004. Consumer preference survey of satsuma mandarins. HortScience 39:1664-1669.

Campbell, B.L., R.G. Nelson, R.C. Ebel, and W.A. Dozier. 2006. Mandarin attributes preferred by consumers in grocery stores. HortScience 41:664-670.

Campbell, J. 2005. Postharvest handling of satsuma mandarins to enhance color and maintain quality. Department of Horticulture, Auburn University, AL, MS Thesis.

Davies, F.S., L.W. Rippetoe, and L.K. Parsons. 1987. Intermittent microsprinkler irrigation and tree wraps for freeze protection of young 'Hamlin' orange trees. HortScience 22:206-208.

Dozier, H.L. 1924. Insect pests and diseases of the satsuma orange. Gulf Coast Citrus Exchange, Educ. Bull. No. 1, Mobile, AL.

Ebel, B., M. Nesbitt, D. Findley, B. Wilkins, D. Himelrick, and S. Burchett. 2000. Response of satsuma mandarin to midwinter defoliation, p. 699. Proc. Intl. Soc. Citricult. IX Congr., Orlando, FL, 3-7 Dec.

Ebel, R.C., B. Campbell, M.L. Nesbitt, W.A. Dozier, J. Lindsey, and B.S. Wilkins. 2005. A temperature index model to determine freeze risk of satsuma mandarins grown on the northern coast of the Gulf of Mexico. J. Amer. Soc. Hort. Sci. 130:500-507.

Ebel, R.C., M. Nesbitt, W.A. Dozier, B. Hockema, F.M. Woods, R. Thomas, R. McDaniel, and B.S. Wilkins. 2004. Fruit quality of satsuma mandarin grown on the northern coast of the Gulf of Mexico. HortScience 39:979-982.

Iba, K. 2002. Acclimative response to temperatures stress in higher plants: Approaches of gene engineering for temperature tolerance. Annu. Rev. Plant Biol. 53:225-246.

Lang, P., C. Zhang, R.C. Ebel, F. Dane, and W.A. Dozier. 2005. Identification of cold acclimated genes in leaves of Citrus unshiu by mRNA differential display. Gene 359:311-318.

Nesbitt, M.L., R.C. Ebel, W.A. Dozier, N.R. McDaniel, and D.G. Himelrick. 2000. Performance of satsuma mandarin protected from freezing temperatures by microsprinkler irrigation. HortScience 35:856-859.

Nesbitt, M.L., R.C. Ebel, D. Findley, B. Wilkins, F. Woods, and D. Himelrick. 2002. Assays to assess freeze injury of satsuma mandarin. HortScience 37:871-877.

Nolte, K.D., A.D. Hanson, and D.A. Gage. 1997. Proline accumulation and methylation to proline betaine in citrus: Implications for genetic engineering of stress resistance. J. Amer. Soc. Hort. Sci. 122:8-13.

Parsons, L.R., T.A. Wheaton, N.D. Faryna, and J.L. Jackson. 1991. Elevated microsprinklers improve protection of citrus trees in an advective freeze. HortScience 26:1149-1151.

Rieger, M. 1989. Freeze protection for horticultural crops. Hort. Rev. (Amer. Soc. Hort. Sci.) 11: 45-109.

Rieger, M., L.K. Jackson, and F.S. Davies. 1985. Freeze survival, trunk temperature and regrowth of young 'Hamlin' orange trees as affected by tree wraps and microsprinkler irrigation. Proc. Florida. State Hort. Soc. 98:60-62.

Rieger, M., F.S. Davies, and L.K. Jackson. 1986. Microsprinkler irrigation and microclimate of young orange trees during freeze conditions. HortScience 21:1372-1374.

Rieger, M., G.H. Smerage, F.S. Davies, and L.K. Jackson. 1988a. Modeling and simulation of tree wraps and microsprinkler irrigation for young citrus freeze protection: I. Model development and validation. J. Amer. Soc. Hort. Soc. 113:808-813

Rieger, M., G.H. Smerage, F.S. Davies, and L.K. Jackson. 1988b. Modeling and simulation of tree wraps and microsprinkler irrigation for young citrus freeze protection: I. Factors affecting protection. J. Amer. Soc. Hort. Soc. 113:813-818.

Spiegel-Roy, P. and E.E. Goldschmidt. 1996. Biology of citrus. Cambridge University Press, New York.

Tignor, M.E., F.S. Davies, and W.B. Sherman. 1998. Freezing tolerance and growth characteristics of USDA intergeneric citrus hybrids US 119 and Selection 17-11. HortScience 33:744748 . 
Williams, P.F. 1911. The satsuma orange. The Alabama Agricultural Experiment Station of the Alabama Polytechnic Institute, Bull No. 157.

Winberg, O.F.E. 1948a. The Satsuma. Fairhope Courier, 7 Oct. Issue. Daily periodical published in Fairhope, AL.

Winberg, O.F.E. 1948b. The Satsuma. Fairhope Courier, 21 Oct. Issue. Daily periodical published in Fairhope, AL.

Winberg, O.F.E. 1948c. The Satsuma. Fairhope Courier, 28 Oct. Issue. Daily periodical published in Fairhope, AL.
Yelenosky, G. 1985. Cold hardiness in citrus. Hort. Rev. (Amer. Soc. Hort. Sci.) 7:201-238.

Yelenosky, G., R.T. Brown, and C.J. Hearn. 1973. Tolerance of trifoliate orange selection and hybrids to freezes and flooding. Proc. Fla. State Hort. Soc. 86:99-104.

Zhang, C., P. Lang, F. Dane, R.C. Ebel, N.K. Singh, R.D. Locy, and W.A. Dozier. 2005a. Cold acclimation induced genes of trifoliate orange (Poncirus trifoliata). Plant Cell Rep. 23:764-769.

Zhang, C., P. Lang, R.C. Ebel, F. Dane, N.K. Singh, R.D. Locy, and W.A. Dozier. 2005b.
Down-regulated gene expression of Poncirus trifoliata under cold acclimation using mRNA differential display. Can. J. Plant Sci. 23:417424.

Zhang, C., M. Nesbitt, F. Dane, and B. Ebel. 2002. Cold hardiness and genetic relationships among Satsuma mandarin cultivars, p. 504 505. American Society for Horticultural Science and the International Society for Horticultural Science joint annual meeting, Toronto, Canada, 10-16 Aug., XXVIth Int. Hort. Cong. \& Exhibition (abstr) 